\title{
Feeding habits of the striped red mullet, Mullus surmuletus in the eastern Adriatic Sea
}

\author{
Mišo PAVIČIĆ, Jasna ŠILJIĆ, Dajana BRAJČIĆ JURICA and Sanja MATIĆ-SKOKO* \\ Institute of Oceanography and Fisheries, Šetalište Ivana Meštrovića 63, P.O. Box. 500, \\ 21000 Split, Croatia
}

*Corresponding author: sanja@izor.hr

\begin{abstract}
Feeding habits of the striped red mullet, Mullus surmutetus in the eastern Adriatic Sea were investigated. Stomach contents of 203 specimens (11.5 - $32.9 \mathrm{~cm}$ TL) collected by bottom trawling were analyzed. Commonly accepted procedures were followed during the diet composition inspection and standard keys were used for food items determination. Examinations showed that 39 identified prey taxa belong to 11 major systematic groups: Crustacea, Gastropoda, Bivalvia, Pisces, Cnidaria, Echinodermata, Polychaeta, Nematoda, Bryozoa, Algae and Rhizaria. The predominant and preferred prey category was decapod crustaceans within all size categories and only in the largest individuals, the dominance of Bivalvia followed by Polychaeta and Crustacea were found. The largest individuals also showed more variety in consumption of different prey categories and a higher mean number of prey items in comparison with smaller fish. No significant differences in prey foraging between males and females $(p>0.05)$ and regarding to season $(p>0.05)$ were found. Feeding on such wide spectra of prey without significant variations regarding to sex and season suggests that the striped red mullets are able to adapt to shifts in spatio-temporal variations in the abundance of potential prey. Presence of detritus in the digestive tracts is highly related to its foraging behaviour on muddy detritic bottoms.
\end{abstract}

Key words: feeding, Mullus surmuletus, Adriatic Sea

\section{INTRODUCTION}

The food web models are very valuable tools in measuring species' importance in an ecosystem (POLIS \& WINEMILLER, 1995; BELGRANO et al., 2005; DE RUITER et al., 2005). Although they may become very complex resulting in uncertain causal relationships between distinct species, such models allow the estimation of the number of indirect interactions between organisms of the same or different trophic levels and evaluation of the overall trophic 'connectedness' of a single species within an ecosystem.
Among fishes, goatfishes may provide important ecosystem services, including resuspension and the formation of mixed species foraging associations due to their very active foraging behaviour with vigorous stirring up of sediments by their barbells and mouths (RANDALL, 1967; GOLANI \& GALIL, 1991; UIBLEIN, 1991; MCCORMICK, 1995; KRAJEWSKI et al., 2006). These characteristics of their resource use make the goatfishes essential components of food webs in coastal ecosystems. Goatfishes have relatively rarely been considered in food web models, especially at the level of single species (UIBLEIN, 
2007). The reason for this is probably derives from insufficient information on their feeding biology in the respective habitat/area, mostly sandy bottoms adjacent to hard bottoms, including coral reefs.

Despite the lack of biological information (AJEMIAN et al., 2016) the striped red mullet, Mullus surmuletus Linnaeus, 1758 is a very important species from an economical and ecological point of view in the Mediterranean littoral benthic communities (STAGLIČIĆ et al., 2011) and highly exploited species by Mediterranean demersal (REŇONES et al., 1995; MEHANNA, 2009) and small-scale (MATIĆ-SKOKO et al., 2011; GFCM, 2015; GFCM, 2017) fisheries. It is distributed in the Eastern Atlantic Sea from the North Sea to Senegal and throughout the Mediterranean and Black seas (WHITEHEAD et al., 1986). The striped red mullet is a bottom-dwelling species, inhabiting shallow soft bottoms, seagrass beds and rocky bottoms (LOMBARTE et al., 2000; BAUTISTA-VEGA, 2008; TSERPES et al., 2002), usually between 10 and $80 \mathrm{~m}$. Spawning occurs in spring period (AMIN et al., 2016). Striped red mullet becomes mature after its first year for both sexes (AMIN et al., 2016). Like other goatfishes (HOLLAND et al., 1993; MEYER et al., 2000), M. surmuletus shows daily short-distance movements within and among foraging and resting sites preying on small benthic invertebrates such as shrimps, amphipods, polychaetes, mollusks and benthic fishes (LABROPOULOU et al., 1997; LOMBARTE et al., 2000; MEHANNA, 2009). Seasonal migrations and formation of spawning aggregations that are known for sympatric species red mullet, Mullus barbatus (MACHIAS \& LABROPOULOU, 2002) are not well expressed for $M$. surmuletus. Juveniles are often encountered on soft bottoms, seagrass beds and at different depths than adults, reflecting both horizontal and vertical ontogenetic habitat shifts. While young show a tendency of forming groups, adults usually live solitary or in smaller groups (JARDAS, 1996).

Foraging behaviour and consequently diet are not stable and may significantly change among different habitats, but also during life history. The aim of this study is to investigate ontogenetic shifts and seasonal fluctuations in resource use in the Adriatic Sea striped red mullet, Mullus surmuletus, with size-/age-/sex-related change in pray foraging on typical muddy detritic bottoms.

\section{MATERIAL AND METHODS}

The total of 203 individuals of Mullus surmuletus were caught using bottom trawls (40 $\mathrm{mm}$ square mesh size) at depths from 80 to $160 \mathrm{~m}$ in the Jabuka Pit area (middle Adriatic: $43^{\circ} 35^{\prime} 30.20^{\prime \prime} \mathrm{N} 15^{\circ} 45^{\prime} 35.38^{\prime \prime}$ E). The samples were taken in December 2011 and through 2012 year in the following months: January, February, March, April, May and October. After being caught the specimens were immediately transported to laboratory for examination. All specimens were weighted to nearest $0.1 \mathrm{~g}$ and their total length (TL) measured to nearest $\mathrm{mm}$. Sex of every fish was determined. The lengthweight relationship was expressed with equation $\mathrm{W}=\mathrm{aL}$; where $\mathrm{W}$ is total body weight, $\mathrm{L}$ is total length, while $a$ and $b$ are constants. The gonadosomatic index (GSI) was calculated using equation GSI $=($ gonad weight/fish weight $) * 100$.

All specimens (138) that contained prey items were divided in $10 \mathrm{~mm}$ TL classes in order to determine frequency and numerical abundance of a certain prey group in stomachs related to fish size. For qualitative and quantitative diet analysis, digestive tracts were weighed (wet weight) and preserved in a 4\% formaldehyde for the examination of their contents. Afterwards, in the laboratory, gut contents were identified and the number of empty stomachs was shown as the vacuity index $(\% \mathrm{VI})$. Stomach contents were examined under a dissecting microscope using reflected light. Each dietary item was identified to the lowest possible taxon, counted and weighed to the nearest $0.01 \mathrm{~g}$. Item weight was obtained by wet weight method. All fragments of some prey groups were put on previously weighed filter paper and left for a few hours at room temperature. Semidry filter paper was then weighed to a precision of $0.001 \mathrm{~g}$. A true weight was obtained as the diference between wet filter paper together with prey organisms and the known dry filter paper weight. The level 
Table 1. Percent frequency of occurrence $(\% F)$, percent of total number $(\% N)$, percent of total weight $(\% W)$ and percent index of relative importance (\%IRI) for food items in Mullus surmuletus

\begin{tabular}{|c|c|c|c|c|c|c|}
\hline \multicolumn{3}{|c|}{ Food items } & $\mathrm{F}(\%)$ & $\mathrm{N}(\%)$ & $\mathrm{W}(\%)$ & $\operatorname{IRI}(\%)$ \\
\hline \multicolumn{3}{|c|}{ Crustacea } & 54.39 & 58.16 & 65.03 & 81.66 \\
\hline \multicolumn{3}{|c|}{ Non-identified Crustacea } & 23.91 & 29.27 & 40.32 & 76.54 \\
\hline \multicolumn{3}{|l|}{ Decapoda } & 2.90 & 6.50 & 4.52 & 1.47 \\
\hline \multirow[t]{2}{*}{ Natania } & Palaemonetes & & 0.72 & 0.41 & 0.32 & 0.02 \\
\hline & Penaeidae & & 0.72 & 0.81 & 0.18 & 0.03 \\
\hline \multirow[t]{21}{*}{ Eucarida } & Galatheidae & & 4.35 & 2.44 & 2.44 & 0.98 \\
\hline & & Galathea squamiffera & 1.45 & 0.81 & 0.32 & 0.08 \\
\hline & & Galathea strigosa & 0.72 & 0.81 & 0.09 & 0.03 \\
\hline & & Munida rugosa & 0.72 & 0.41 & 1.45 & 0.06 \\
\hline & Leucosiidae & Ilia nucleus & 0.72 & 0.41 & 0.18 & 0.02 \\
\hline & & Ebalia sp. & 0.72 & 0.41 & 0.18 & 0.02 \\
\hline & & Ebalia granulosa & 0.72 & 0.81 & 0.32 & 0.04 \\
\hline & Xanthidae & & 2.17 & 4.47 & 4.71 & 0.92 \\
\hline & & Xantho pilipes & 0.04 & 0.031 & 0.009 & 0.088 \\
\hline & & Xantho poressa & 0.72 & 0.41 & 0.18 & 0.02 \\
\hline & & Monodaeus couchii & 0.72 & 0.41 & 0.23 & 0.02 \\
\hline & Portunidae & & 2.90 & 2.44 & 1.13 & 0.48 \\
\hline & & Bathynectes longipes & 0.72 & 0.41 & 0.36 & 0.03 \\
\hline & & Macropipus corrugatus & 2.17 & 1.22 & 2.53 & 0.38 \\
\hline & & Macropipus pusilus & 0.72 & 0.41 & 1.72 & 0.07 \\
\hline & & Liocarcinus arcuatus & 0.72 & 0.41 & 0.23 & 0.02 \\
\hline & Paguridae & & 0.72 & 0.41 & 0.54 & 0.03 \\
\hline & & Parthenopeidae & 1.45 & 0.81 & 0.32 & 0.08 \\
\hline & Grapsidae & Pachygrapsus marmoratus & 0.72 & 1.63 & 0.63 & 0.08 \\
\hline & Pilumnidae & Pilumnus hirtellus & 1.45 & 0.81 & 0.27 & 0.07 \\
\hline & Majidae & Pisa nodipes & 0.72 & 0.81 & 0.95 & 0.06 \\
\hline \multicolumn{3}{|c|}{ Amphipoda } & 0.72 & 0.41 & 0.90 & 0.04 \\
\hline \multicolumn{3}{|c|}{ Gastropoda } & 2.17 & 2.44 & 0.32 & 0.09 \\
\hline \multicolumn{3}{|c|}{ Non-identified Gastropoda } & 0.72 & 0.81 & 0.09 & 0.03 \\
\hline & Nassariidae & Hinia sp. & 0.72 & 0.41 & 0.05 & 0.02 \\
\hline & Cerithiidae & Bittium reticulatum & 0.72 & 1.22 & 0.18 & 0.05 \\
\hline \multicolumn{3}{|l|}{ Bivalvia } & 13.04 & 18.29 & 8.01 & 6.94 \\
\hline \multicolumn{3}{|c|}{ Non-identified Bivalvia } & 7.25 & 9.35 & 4.43 & 4.59 \\
\hline & Limidae & Limulata subovata & 0.72 & 0.41 & 0.09 & 0.02 \\
\hline & Pectinidae & Palliolum incomparabile & 0.72 & 0.41 & 0.05 & 0.02 \\
\hline & Solemidae & Solemya togata & 4.35 & 8.13 & 3.44 & 2.31 \\
\hline \multicolumn{3}{|l|}{ Pisces } & 5.07 & 3.25 & 0.77 & 0.94 \\
\hline \multicolumn{3}{|l|}{ Cnidaria } & 1.45 & 0.81 & 0.14 & 0.06 \\
\hline \multicolumn{3}{|l|}{ Anthozoa } & 1.45 & 0.81 & 0.14 & 0.06 \\
\hline
\end{tabular}




\begin{tabular}{lccccc}
\hline Echinodermata & & $\mathbf{3 . 6 2}$ & $\mathbf{4 . 0 7}$ & $\mathbf{4 . 3 4}$ & $\mathbf{1 . 0 7}$ \\
Echinoidea & Regularia & 0.72 & 0.41 & 0.09 & 0.02 \\
& & 2.90 & 3.66 & 4.25 & 1.05 \\
\hline Polychaeta & $\mathbf{9 . 4 2}$ & $\mathbf{6 . 1 0}$ & $\mathbf{1 0 . 6 3}$ & $\mathbf{7 . 2 5}$ \\
\hline Non-identified Polychaeta & 9.42 & 6.10 & 10.63 & 7.25 \\
\hline Nematoda & $\mathbf{2 . 9 0}$ & $\mathbf{2 . 8 5}$ & $\mathbf{9 . 7 7}$ & $\mathbf{1 . 6 8}$ \\
\hline Bryozoa & $\mathbf{2 . 1 7}$ & $\mathbf{1 . 2 2}$ & $\mathbf{0 . 3 6}$ & $\mathbf{0 . 0 9}$ \\
Non-identified Bryozoa & 1.45 & 0.81 & 0.32 & 0.08 \\
& Margaretta cereoides & 0.72 & 0.41 & 0.05 & 0.02 \\
\hline Algae & & $\mathbf{2 . 9 0}$ & $\mathbf{1 . 6 3}$ & $\mathbf{0 . 2 3}$ & $\mathbf{0 . 2 5}$ \\
\hline Rhizaria & & $\mathbf{0 . 7 2}$ & $\mathbf{0 . 4 1}$ & $\mathbf{0 . 0 5}$ & $\mathbf{0 . 0 2}$ \\
Foraminifera & Elphidium crispum & 0.72 & 0.41 & 0.05 & 0.02
\end{tabular}

of identification depended on the completeness of the food degradation and its condition.

Quantitative analysis is presented using three standard indices: the percentage frequency of occurrence $(\% \mathrm{~F}=$ the number of stomachs containing prey item/ total number of non-empty stomachs $\mathrm{x} 100)$; the percentage numerical abundance $(\% \mathrm{~N}=$ the number of prey items of a given prey category in all non- empty stomachs/ total number of prey items in all stomachs $\mathrm{x} 100)$; the gravimetric percentage $(\% \mathrm{~W}=$ the weight of prey items of a given prey category in all non- empty stomachs/ total weight of food items in all stomachs x 100) (HYSLOP, 1980). To get more precise results of diet we used the index of relative importance (\%IRI), modified by HACUNDA (1981) [IRI $=(\% \mathrm{~N}+\% \mathrm{~W}) \mathrm{x} \%$ F], expressed as percentage [(IRI / $\Sigma$ IRI) x 100].

Sexual and seasonal differences in diet were evaluated with multivariate PERMANOVA and non-metric multidimensional scaling (MDS) plot (PRIMER v6). Data were square-root transformed and a similarity matrix was constructed using the Bray-Curtis similarity coefficient.

\section{RESULTS}

A total of 203 Mullus surmuletus individuals ranged from 11.5 to $32.9 \mathrm{~cm}$ TL, with an average of $17.29 \mathrm{~cm}( \pm 3.34 \mathrm{SD})$. Weight ranged from 18.39 to $432.25 \mathrm{~g}$, with an average of 68.86 ( $\pm 49.91 \mathrm{SD})$. The total sample was represented by 124 male and 79 female individuals. The length distribution of males was from 11.9 to $28.6 \mathrm{~cm}$, with an average of $17.19 \mathrm{~cm} \pm 2.99$ $\mathrm{SD}$, while in female individuals TL ranged from 11.5 to $32.9 \mathrm{~cm}$, with an average of $17.38 \mathrm{~cm} \pm$ 3.84 SD. Both, male and female specimens were divided in the $10 \mathrm{~mm}$ TL size classes (Fig. 1). Weight ranged from 14.88 to $275.34 \mathrm{~g}$ for males, with an average of $64.75 \mathrm{~g} \pm 38.21 \mathrm{SD}$, while females' weight ranged from 18.39 to $432.25 \mathrm{~g}$, with an average of $77.11 \pm 64.57 \mathrm{SD}$.

The calculated length-weight equation for the whole sample was $\mathrm{W}=0.017 \mathrm{TL}^{2.871}\left(\mathrm{R}^{2}=0.949\right)$. This relationship for males was described by the parameters $\mathrm{a}=0.022$ and $\mathrm{b}=2.774\left(\mathrm{R}^{2}=0.926\right)$ and for females by the parameters $\mathrm{a}=0.013$ and $\mathrm{b}=2.974\left(\mathrm{R}^{2}=0.978\right)$ (Fig. 2). The gonadosomatic index for both sexes varied from 0.48 to 1.7 and was highest in spring and lowest in autumn (Fig. 3).

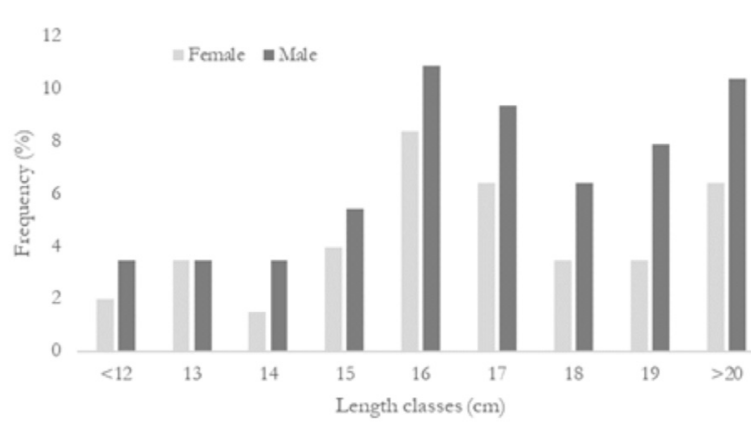

Fig. 1. Frequencies of females and males of Mullus surmuletus according to size classes 


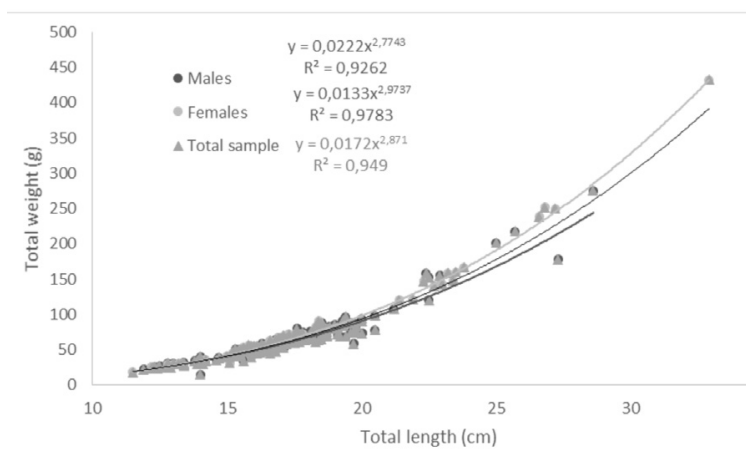

Fig. 2. Length-weight relationship of females and males of Mullus surmuletus

In total, 65 digestive tracts were empty $(\% \mathrm{VI}=32.02 \%)$. The highest number of empty stomachs were recorded during autumn for females $(\% \mathrm{VI}=28.13 \%)$ and during spring for males $(\% \mathrm{VI}=60.0 \%)$. The greatest vacuity index was noticed in size class $<12 \mathrm{~cm}$ for females with maximum value of $100 \%$, while in larger classes $(18,19$ and $>20 \mathrm{~cm})$ there were no empty stomachs. The diet of $M$. surmuletus consisted of at least 39 prey taxa belonging to 11 major systematic groups (Crustacea, Gastropoda, Bivalvia, Pisces, Cnidaria, Echinodermata, Polychaeta, Nematoda, Bryozoa, Algae and Rhizaria). The relative importance of different prey groups and taxa is given in the Table 1. According to the index of relative importance crustaceans dominated $(\% \mathrm{IRI}=81.66)$ and they are the most frequent prey group $(\% \mathrm{~F}=54.39)$, so they can be regarded as the preferred food. Polychaetes (\%IRI $=7.25$ ) occurred in $9.42 \%$ of the analysed specimens. Bivalves $(\% \mathrm{IRI}=6.94)$ were found in $13.04 \%$ of stomachs, and the most numerous species was Solemya togata $(\% \mathrm{~F}=4.35)$. Accord-

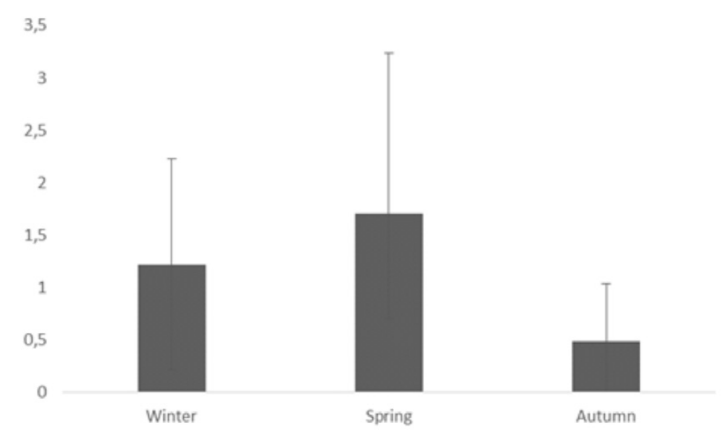

Fig. 3. Sesonal variation of the gonadosomatic index (GSI)

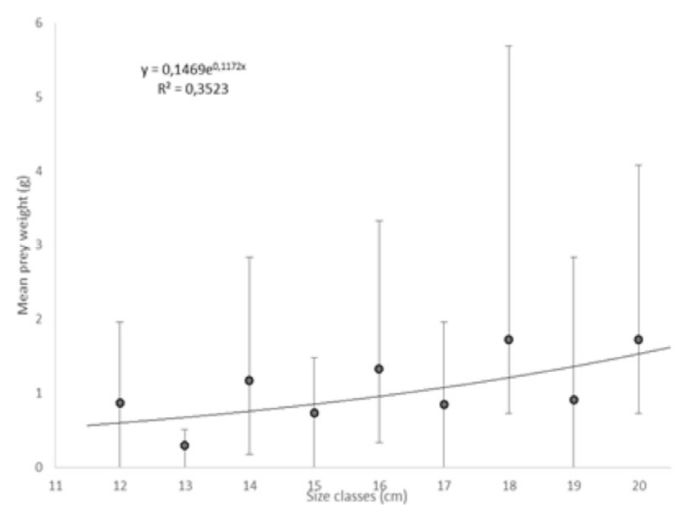

Fig. 4. Distribution of mean prey weight among the size classes in Mullus surmuletus

ing to the frequency of occurrence, polychaetes and bivalves can be considered as secondary food. Other prey groups are categorized as random food.

The weight of ingested material varied with a size of fish, with its maximum of $15.8 \mathrm{~g}$ at the length of $18 \mathrm{~cm}$. The lowest value of prey mass $(\mathrm{W}=0.03)$ was noticed in smaller specimens, in $13 \mathrm{~cm}$ size class. The average of prey weight was $1.84 \mathrm{~g} \pm 2.08 \mathrm{SD}$ (Fig. 4).

The number of ingested items mostly increased with the fish size classes. Maximal number of ingested prey items $(\mathrm{N}=40)$ was recorded in the $16 \mathrm{~cm}$ size class. In the smaller size classes $(<12,13,14 \mathrm{~cm})$ a significantly lower mean number of prey items (1.49) was noticed. In the larger size classes $(17,18,19,>20$ $\mathrm{cm})$ the average number of ingested prey items was 2.9. In total, the average number of ingested items per fish was $2.46( \pm 6.17 \mathrm{SD})$ (Fig.5).

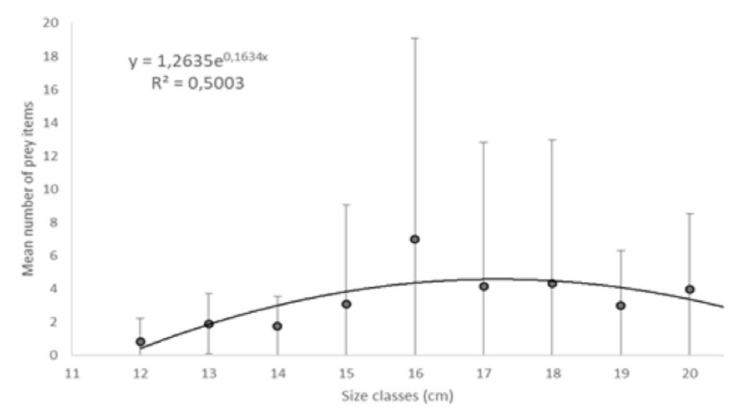

Fig. 5. Relationship between the mean number of prey items and the size classes of Mullus surmuletus 


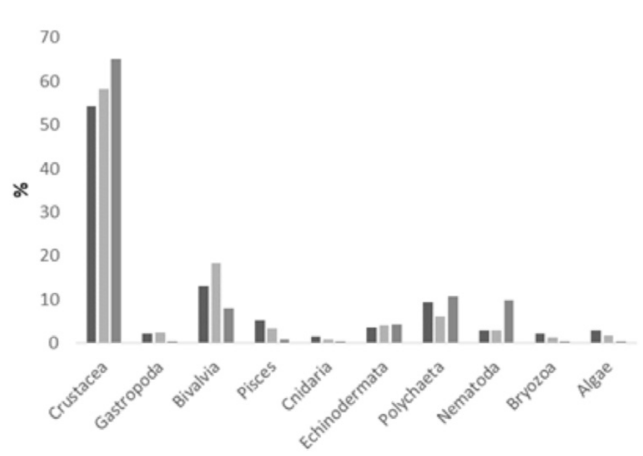

Fig. 6. The frequency of occurrence (F\%), numerical abundance (N\%) and percentage weight (W\%) of main prey categories in Mullus surmuletus

Crustaceans were the predominant prey category regarding frequency $(\% \mathrm{~F}=54.38)$, numerical abundance $(\% \mathrm{~N}=58.16)$ and weight $(\% \mathrm{~W}=65.03)$. Apart from Crustacea, Bivalvia $(\% \mathrm{~F}=13.04)$ and Polychaeta $(\% \mathrm{~F}=9.4)$ had considerably smaller contributions and reached $18.29 \%$ and $6.1 \%$ by numerical abundances $(\% \mathrm{~N})$, respectively. Apart from Crustacea $(\% \mathrm{~W}=63.05)$ and Polychaeta $(\% \mathrm{~W}=10.63)$, only Nematoda and Bivalvia slightly contributed in weight of prey items with $9.77 \%$ and $8.01 \%$, respectively. Other taxa found within the $M$. surmuletus prey spectra were of less importance (Fig. 6).

Crustaceans were the predominant prey taxa according to \%IRI index in all size categories, except in the $>20 \mathrm{~cm}$ size class, where the most diverse prey composition is recorded. In that size class $(>20 \mathrm{~cm})$, the dominant prey

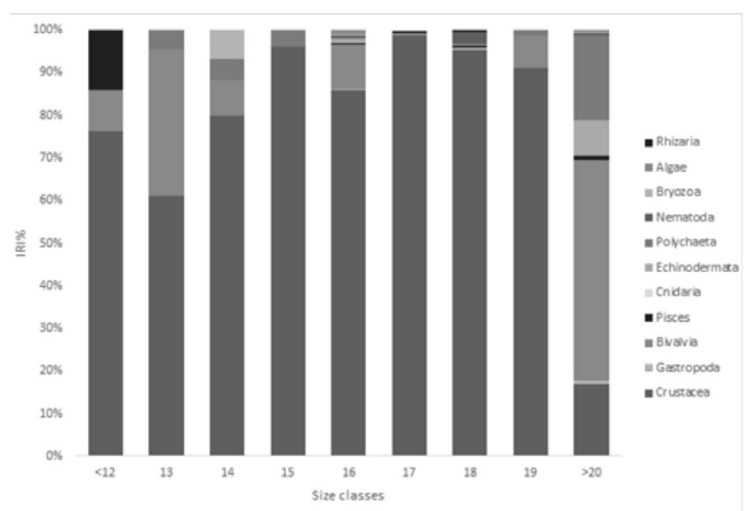

Fig. 7. Composition of Mullus surmuletus diet as a function of size, based on the \%IRI values of the major prey groups

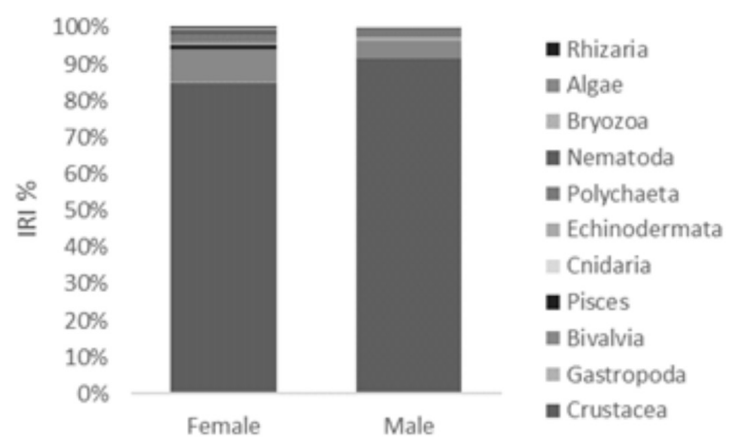

Fig. 8. The diet composition based on IRI\% of Mullus surmuletus regarding sex

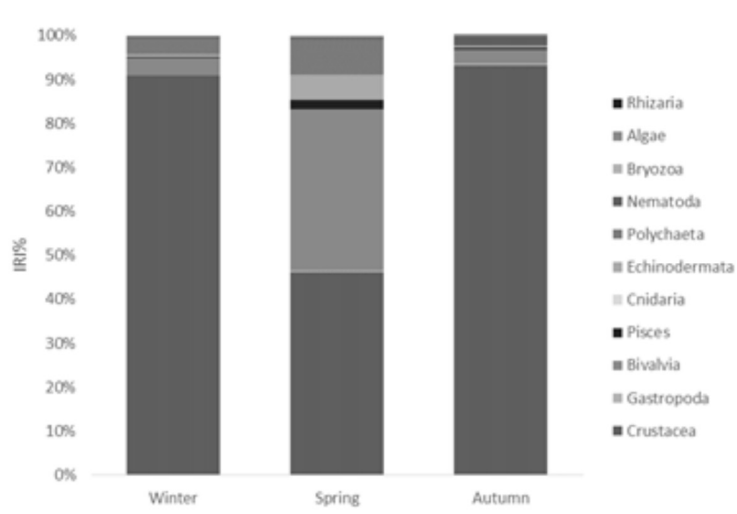

Fig. 9. Seasonal variation of Mullus surmuletus diet based on the \%IRI values of the major prey groups

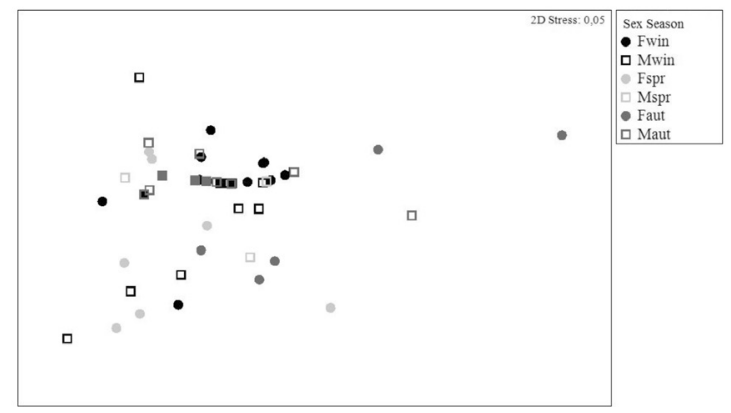

Fig. 10. Multidimensional scaling (MDS) plot of the $W$ prey categories in the stomachs of $M$. surmuletus ( $F$ - female, $M$ - male, win - winter, spr - spring, aut autumn)

category was Bivalvia with 52.54 (\%IRI), followed by Polychaeta $(\% \mathrm{IRI}=20.11)$ and Crustacea $(\% \mathrm{IRI}=17.21)$ (Fig. 7$)$.

Similar prey spectra dominated by crustaceans with values of $\% \mathrm{IRI}=85.16$ for females and \%IRI=91.74 for males was recorded. Bivalvia prey group contributed more to females' diet 
$(\% \mathrm{IRI}=8.88)$ than for males $(\% \mathrm{IRI}=4.76)$. Other prey groups were less represented (Fig. 8).

Similar prey composition in term of \%IRI index was recorded during winter and autumn, with the values higher than $90 \%$ for Crustacea in both seasons. In the spring period, the striped red mullet showed more diverse prey spectra according to the contribution of other prey groups. Apart from the Crustacea (\%IRI $=46.19)$, other prey like Bivalvia (\%IRI=35.59), Polychaeta $(\% \mathrm{IRI}=8.07)$ and Echinodermata $(\% \mathrm{IRI}=5.67)$ contributed more to the diet in spring than in colder months (Figure 9). However, multivariate PERMANOVA showed similar diet composition regarding sex and season $(p>0.05)$ and MDS plot revealed it (Fig. 10).

\section{DISCUSSION}

Due to known species-specific differences in goatfish foraging behaviour and diet selection, it may be preferable to include in ecological studies and food web models only those species that have been thoroughly studied (UIBLEIN, 2007), particularly for the often co-occurring red mullet and striped red mullet (LABROPOULOU \& ELEFTHERIOU, 1997; AGUIRRE \& SÁNCHEZ, 2005). In food web models apart from speciesspecific differences, it should also be considered whether goatfishes undergo ontogenetic shifts in foraging behaviour, diet, and habitat selection (UIBLEIN, 1991; LABROPOULOU et al., 1997).

The diet of the striped red mullet, Mullus surmuletus, in the Adriatic had not been studied until now, although generally diet composition data exist in the literature (LABROPOULOU et al., 1997; LOMBARTE et al., 2000; MEHANNA, 2009; AJEMIAN et al., 2016). However, due to growing awareness that goatfishes, particularly $M$. surmuletus in the Mediterranean, are potentially good ecological indicators of anthropogenic impact (UIBLEIN, 2007) and this family is put under the specific request for replenishment of the biological data gap. UIBLEIN (2007) emphasised that goatfishes respond to human-induced factors such as fisheries and habitat modification, as reflected by their abundance, size, weight changes, or changes in their distributional range. Thus, the temperature increase may lead to changes in the reproductive or growth rates and longer warming periods may induce goatfishes to migrate to higher latitudes, as exemplified by $M$. surmuletus in the North Sea (BEARE et al., 2004). It is very important to reveal the spatial framework of growth, age, and reproduction for these Mullus species. Since foraging behaviour and feeding itself are essential in shaping all life parameters, the importance of such data is an obvious necessity.

The length and weight range together with length-weight relationship in this study revealed that analyzed Mullus surmuletus specimens exhibited negative allometric growth $(b=2.871)$. Previous research conducted by DULČIĆ \& KRALJEVIĆ (1996) for M. surmuletus within similar length range (15.4 - $30.9 \mathrm{TL})$, suggested positive allometric growth $(b=3.512)$. Moreover, other authors (FROSER \& PAULY, 1998; MOUTOPOULOS \& STERIGIOU, 2002; ARSLAN \& ISMEN, 2013) also reported positive allometric growth. Such difference in findings can be a consequence of several factors affecting the sample composition like salinity fluctuations, sex ratio, food availability, season and maturity stage of the inspected fish (SHEPHERD \& GRIMES, 1983; PAULY, 1984; CHERIF et al., 2007). Generally, lower growth in weight implies higher energy consumption and/or lower energy gain due to the lack of suitable or desirable prey in the habitat. However, this may result in with a lower condition factor that can further affect foraging behaviour and consequently other psychological processes.

Higher percentage of premature and mature individuals and individuals that just spawned in the total sample may affect length-weight relationship due to the higher or lower gonadosomatic index (GSI), respectively. In this study, the average values of GSI increased from winter $(\mathrm{GSI}=1.22)$ and reached their maximum $(\mathrm{GSI}=1.70)$ in spring, suggesting spawning period in that season. Such results confirm findings of JARDAS (1996) about the spawning period in the May, June and July for M. surmuletus on the eastern Adriatic coast. ARSLAN \& ISMEN (2013) also noticed an increasing of the gonadosomatic index after winter period, and decreased 
after May, in the North Aegean Sea. Data from Mediterranean and Atlantic (MORALES-NIN, 1991; CAMPILO, 1992; N'DA \& DANIEL, 1993; LAMRINI, 2010; ARSLAN \& ISMEN, 2013) also suggested the spawning period during spring, starting in April and May.

Earlier studies (DULČIĆ, 1996; JARDAS et al., 2004) also confirmed that the spawning period might be influenced by feeding intensity, which can be reflected on the vacuity index of the investigated fish. According to the several investigations in the Adriatic Sea (JARDAS \& PALLAORO, 1991; DULČIĆ, 1996; JARDAS et al., 2004) the highest values of empty stomachs often appeared during the spawning period for different species. In this study, significantly different numbers of empty stomach by sex and season were recorded but without correlation with the spawning period. Further, LABROPOULOU et al. (1997) haven't detected differences in vacuity index among the seasons for M. surmuletus in the Mediterranean Sea. Sea temperature can also be a trigger for an ontogenetic migration of larger specimens in deeper water (LABROPOULOU et al., 1997). In accordance to this, VASSILOPOULOU et al. (2001) reported that the highest values of the vacuity index in the striped red mullet from the Aegean Sea were found at larger specimens. Similar results have been reported in the north eastern Mediterranean by LABROPOULOU et al. (1997), where the maximum of vacuity index $(\mathrm{VI}=57.89 \%)$ was obtained in largest individuals. In this study, males had lower number of empty stomachs in the smaller size categories while no empty stomachs were found in the largest females. Moreover, the highest number of empty stomachs has been recorded in smaller individuals. However, higher percentage of empty stomach can be consequence of the catch method, particularly, trawl survey could affect the vacuity index.

In general, crustaceans were the dominant prey taxa in all analysed indexes, frequency of occurrence, numerical abundance and weight percentage. Bivalvia and Polychaeta were significantly less presented in $M$. surmuletus diet by the mentioned indexes, while other prey taxa were in undistinguished proportions. LABROPULOU \& ELEFTHERIOU (1997) studying foraging ecology of demersal fish also found Decapoda as the predominant prey by number and weight in $M$. surmuletus diet. The same was reported by GOLANI \& GAIL (1991) and VASSILOPOULOU et al. (2001). Despite decapods being the most frequent crustaceans, mysids and euphasids were also numerically important while fish were represented with low contribution $(\% \mathrm{~W}=9 \%)$ and consumption of cephalopods by larger specimens were observed (VASSILOPOULOU et al., 2001). However, N'DA (1992) observed the important role of the pelagic prey in the diet of the same species on the French Atlantic coast.

Considering the contribution of a specified prey by \%IRI, a dietary importance of ingested preys can be determined. Results presented in this study highlighted preference on the Crustacea $(\% \mathrm{IRI}=81.66)$ following by Polychaeta $(\% \mathrm{IRI}=7.25)$ and Bivalvia (\%IRI=6.94), while other prey taxa were represented with minor importance according to \%IRI. However, some prey taxa can consequently be less represented due to the low level of identification. Numerous studies (BEN-ELIAHU \& GOLANI, 1990; N'DA, 1992; BADALAMENTI et al., 1993; LABROPULOU \& ELEFTHERIOU, 1997; SERRANO et al., 2003) emphasized the importance of motile and carnivorous species in the diet of the striped red mullet. Thus, BAUTISTA-VEGA et al. (2008) reported dominance of motile surface and sub-surface deposit feeding polychaetes in the study from the north-west Mediterranean Sea. In general, preying mostly on crustaceans, polychaetes, bivalves, ophiurids and amphipods indicates feeding behaviour of this species. Furthermore, a lot of inorganic material of sediment origin has been found in the digestive tracts of the striped red mullet from the eastern Adriatic Sea. MAZZOLA et al. (1999) reported presence of detritus in Mullus surmuletus digestive tracts, which can be related to the foraging behaviour of the investigated species. Namely, M. surmuletus ingested detritus together with prey organisms detected in the sediment using barbels (LOMBARTE \& AGUIRRE, 1997). Definitely, this is a reflection of living on muddy detritic bottoms. Surely, diet comparison of specimens inhabiting different bottoms and depths are necessary in future investigations. 
Apart from feeding intensity, the fish size can also influence the prey composition of the diet. A number of authors (GOLANI \& GALIL, 1991; GOLANI, 1994; GUILLEN \& MARRTINEZ, 1995) recorded different pray selection according to fish size, as well as in the different ontogenetic stadium. While characteristic prey categories for adults were Crustacea (Decapoda) and Mollusca, MAZZOLA et al. (1999) noticed the dominance of Copepoda, Polychaeta, Amphipoda and Tanaidacea in juveniles. In our study, the predominant prey category was decapod crustaceans within all size categories and only with the largest individuals the dominance of Bivalvia, followed by Polychaeta and Crustacea was expressed. The largest individuals showed more variety in consumption of different prey categories in comparison with smaller fish. It is a well known phenomenon regarding the changes of diet in larger fish caused by the more diversity in prey selection and consequentially a wider range of ingested organisms (WARE, 1972; ROSS, 1977; STONER \& LIVINGSTON, 1984). These changes of diet connected to the fish size can be explained in the striped red mullet with the morphological changes in width and height of its mouth, resulting in a selection of larger prey organisms (ROSS, 1977; STONER \& LIVINGSTON, 1984). Those morphological characteristics are in the relation with fish's feeding behaviour, placing the species in adequate trophic niches (LABROPULOU \& ELEFTHERIOU, 1997). According to morphological changes, LABROPOULOU et al. (1997) have found a predominance of fish and cephalopods in the diet of larger $(>161 \mathrm{~mm})$ $M$. surmuletus specimens. Furthermore, for this species BAUTISTA-VEGA et al. (2008) recorded a diet shift between medium $(110-180 \mathrm{~mm})$ and large $(>180 \mathrm{~mm})$ sized fish. They also reported increased consumption of bivalves and ophiuroids for larger specimens in the comparison with other size classes resulting in significantly different diet composition between large specimens and smaller ones. However, no significant differences between small and medium fish were recorded. BAUTISTA-VEGA et al. (2008) highlighted size related differences in the striped red mullet diet, with increasing consummation of polychaetes with size, and decreasing percentage of small crustaceans in diet of higher size classes. Our results confirm those conclusions. Both investigations indicated possible strong intraspecific competition between small and medium size fish, since differences in feeding habits in relation to size can influence reduced intraspecific competition among the different size classes fish (GROSSMAN, 1980; LANGTON, 1982, HARMELIN-VIVIEN et al., 1989).

Except the changes in diet composition among size, this species showed differences in the ingested food amount. The quantity of the ingested material can be expressed by prey weight and number of prey items. Our results showed a slightly increasing mean prey weight with the size, but with the maximum at $18 \mathrm{~cm}$ size class. Otherwise, we found the lower mean number of prey items in the smaller size classes, in comparison with larger specimens. LABROPOULOU et al. (1997) also noticed an increase of mean prey mass in larger specimens, while the mean number of prey items did not differ with the size. Decreasing mean number of prey items and increasing the mean prey weight in larger size classes can be related to the consumption of larger prey taxa, such as fishes and cephalopods. Prey mass and number distribution in first line depended on the complete diet composition among size classes, so according to our results it was evident that the same type of prey is present in all size classes, only larger amounts of prey were ingested in larger individuals. BAUTISTAVEGA et al. (2008) recorded no significant difference in prey mass percentages among seasons, while LABROPOULOU et al. (1997) noticed an increase of mean prey mass in larger specimens.

No significant differences in food composition between males and females of $M$. surmuletus were found in the present study ( $\mathrm{p}>0.05)$. Decapods dominated in both sex diet, as the most important diet component for the goatfishes in the Mediterranean Sea (BEN-ELIAHU \& GOLANI, 1990; GOLANI \& GALIL, 1991; GOLANI, 1994). Also, no significant seasonal changes in diet composition were found in the present study $(p>0.05)$, but this may be affected because not all months were covered. However, decapods 
were also the most important prey category in the both, winter $(\% \mathrm{IRI}=90.89)$ and autumn period (\%IRI=93.22). In spring, a wider range and higher proportions of some ingested prey taxa, including Crustacea, Bivalvia, Polychaeta and Echinodermata, were recorded. On the other hand, LABROPOULOU et al. (1997) for $M$. surmuletus from Cretan coast, found significant differences in diet among seasons. Namely, in the summer period M. surmuletus fed more on decapods than in the winter and spring period when amphipods dominated in the fish diet. For other prey taxa, including polychaetes, bivalves and mysids, minor contribution to the observed differences were determined. They emphasized that $M$. surmuletus diet contained a narrow range of prey taxa, suggesting the status of specialist in feeding. These findings are opposite to our results. Surely, the spatial and seasonal differences in food composition can be related to the availability of certain prey organisms in a certain environment. Furthermore, the higher contribution of some prey category in the fish diet can also be linked to the presence of certain ecological trophic categories in the study area (LABROPOULOU et al., 1997) and thus not just be a reflection of species preference for specific prey organism but also a reflection of habitat characteristics and potential modifications due to anthropogenic pressure.

Many knowledge gaps still exist in $M$. surmuletus ecology. However, the currently available data suggest that this species may indeed be a suitable habitat indicator and may also qualify as key species in coastal sand-associated ecosystems (UIBLEIN, 1991). Because of considerable intraspecific variations in habitat preferences, food selection, behaviour, and body structure, further exploration, monitoring, and management is still required in the area of its distribution, together with enhancing information exchange and initiating joint research efforts in M. surmuletus ecology.

\section{REFERENCES}

AJEMIAN, M.J., M.D. KENWORTHY, J.L. SÁNCHEZLIZASO \& J. CEBRIAN. 2016. Aggregation dynamics and foraging behaviour of striped red mullet Mullus surmuletus in the western Mediterranean Sea. J. Fish Biol., 88 (5): 2051-2059.

AMIN, A.M., F. F. MADKOUR, ABU EL-REGAL, M.A. \& A.A. MOUSTAFA. 2016. Reproductive biology of Mullus surmuletus (Linnaeus, 1758) from the Egyptian Mediterranean Sea (Port Said). International Journal of Environmental Science And Engineering, 7: 1-10.

ARSLAN, M., \& A. İŞMEN. 2013. Age, growth and reproduction of Mullus surmuletus (Linnaeus, 1758) in Saros Bay (Northern Aegean Sea). Journal of the Black Sea/Mediterranean Environment, 2: 217-233.

BAUCHOT, M.L. 1987. Mullidae. In Fisher W., Bauchot M.L. and Schneider M. (eds) Fichnes FAO didentification des especes pour les besoins de la peche. Rome, FAO, pp. 761-1530.
BAUTISTA-VEGA, A. 2008. Etude des réseaux trophiques aboutissant aux rougets méditerranéens (Mullus barbatus et Mullus surmuletus) par utilisation des isotopes stables. Cybium, 32: 264-265.

BEARE, D. J., F. BURNS, K. PEACH \& REID, D. G. 2004. Red mullet migration into the northern North Sea during late winter. Journal of Sea Research, 53: 205-212.

BELGRANO, A., U. SCHARLER, J. DUNNE \& B. ULANOWICZ. 2005. Aquatic Food Webs: an Ecosystem Approach. Oxford: Oxford University Press., p. 272.

BEN-EliAhU, M. N., \& D. GOLANI. 1990. Polychaetes (Annelida) in the gut contents of Goatfishes (Mullidae), with new polychaete records from the Mediterranean coast of Israel and the Gulf of Elat (Red Sea). Marine Ecology, 11: 193-205.

BEN-TUVIA, A. 1990. Mullidae. In Quero J.C., Hureau J.C., Karrer C., Post A. and Saldanha L. (eds) Check-list of the fishes of the eastern tropical Atlantic (CLOFETA). JNICT, 
Lisbon; SEI, Paris; and UNESCO, Paris. pp. 827-829.

CAMPILLO, A. 1992. Les pêcheries françaises de Méditeranée: synthèse des connaissances. Institut Francais de Recherche pour l'Exploitation de la Mer, France, 206 pp.

CHERIF, M., R. ZARRAD, H. GHARBI, H. MISSAOUF \& O. JARBOUI. 2007. Some biological parameters of the red mullet, Mullus barbatus L., 1758, from the Gulf of Tunis. Acta Adriat., 48 (2): 131-144.

DE RUITER, P.C., V. WOLTERS \& J.C. MOORE. 2005. Dynamic Food Webs. San Diego: Academic Press. 590 pp.

DULČIĆ, J., \& M. KRALJEVIĆ. 1996. Weight-length relationship for 40 fish species in the eastern Adriatic (Croatian waters). Fisheries Research, 28 (3): 243-251.

DULČIĆ, J. 1996. Food and feeding habits of the damselfish Chromis chromis (Teleostei: Pomacentridae) in the eastern Adriatic. Annales for Istrian and Mediterranean studies, 9: 31-36.

FROESE, R. \& D. PAULY. 1998. FishBase 1998. Concepts, design and data sources. Philippines: International Center for Living Aquatic Resources Management, p. 608.

GFCM. 2015. Stock Assessment Form Demersal species for red mullet, Mullus barbatus in 2014 (GSA 17 and GSA 18) (http://www.fao. org $/ \mathrm{gfcm} / \mathrm{data} / \mathrm{safs} / \mathrm{en} /$ ).

GFCM. 2017. Working Group on Stock Assessment of Demersal Species (WGSAD). Final report, GFCM and FAO, Rome, November 2016, 74 pp.

GOLANI, D. \& B. GALIL. 1991. Trophic relationships of colonizing and indigenous goatfishes (Mullidae) in the eastern Mediterranean with special emphasis on decapod crustaceans. Hydrobiologia, 218: 27-33.

GOLANI, D. 1994. Niche separation between colonizing and indigenous goatfish (Mullidae) along the Mediterranean coast of Israel. J. of Fish Biol., 45: 503-513.

GROSSMAN, G. D. 1980. Ecological aspects of ontogenetic shifts in prey size utilization in the Bay goby (Pisces: Gobiidae). Oecologia, 47: 233-238.
GUILLÉN, J. \& M. MARTİNEZ. 1995. Mullus surmuletus (L, 1758) decapoda selective predation. Rapp. Comm. Int. Mer Medit. 34: 244.

HACUNDA, J.S. 1981. Trophic relationships among demersal fishes in a coastal area of the Gulf of Maine. Fishery Bulletin, 79 (4): 775-788.

HARMELIN-VIVIEN, H. L., R. A. KAIM-MALKA, M. LEDOYER \& S. S. JAKOB-ABRAHAM. 1989. Food partitioning among scorpaenid fishes in Mediterranean seagrass beds. J. Fish Biol., 34: 715-734.

HOLLAND, K. N., J.D. PETERSON, C.G. LOWE \& B.M. WETHERBEE. 1993. Movements, distribution and growth rates of the white goatfish Mulloides flavolineatus in a fisheries conservations zone. Bull. of Mar. Sci., 52: 982-992.

HYATT, K. D. 1979. Feeding strategy. In Hoar W. S. and Randall D.J. (Editors). Fish Physiology. New York, Academic Press. pp. 71-119.

HYSLOP, E. J. 1980. Stomach content analysis-a review of methods and their application. Journal of Fish Biology, 17: 411-429.

JARDAS, I. \& A. PALLAORO. 1991. Food and feeding habits of black scor- pionfish (Scorpaena porcus L., 1758) (Pisces: Scorpaenidae) along the Adriatic coast. Acta Adriat., 32: 885-898.

JARDAS, I. 1996. Jadranska ihtiofauna. Zagreb: Školska knjiga, pp 533.

JARDAS, I., M. ŠANTIĆ \& A. PALLAORO. 2004. Diet composition and feeding intensity of horse mackerel, Trachurus trachurus (Osteichthyes: Carangidae) in the eastern Adriatic. Marine Biology, 144: 1051-1056.

KRAJEWSKI, J.P., R.M. BONALDO, C. SAZIMA \& I. SAZIMA. 2006. Foraging activity and behaviour of two goatfish species (Perciformes: Mullidae) at Fernando de Noronha Archipelago, tropical West Atlantic. Environmental Biology of Fishes, 77: 1-8.

LABROPOULOU, M., \& A. ELEFTHERIOU. 1997. The foraging ecology of two pairs of congeneric demersal fish species: importance of morphological characteristics in prey selection. J. Fish Biol., 50: 324-340.

LABROPOULOU, M., A. MACHIAS, N. TSIMENIDES \& A. ELEFTHERIOU. 1997. Feeding habits and ontogenetic diet shift of the striped red mul- 
let, Mullus surmuletus Linnaeus, 1758. Fisheries Research, 31 (3): 257-267.

LAMRINI, A. 2010. Croissance et reproduction du rouget barbet de roche (Mullus surmuletus $\mathrm{L}$. 1758) dans la baie de m'diq (MAROC). Rapp. Comm. int. Mer Médit. 39: 565-565.

LOMBARTE, A. \& H. AGUIRRE. 1997. Quantitative differences in the chemoreceptor systems in the barbels of two species of Mullidae (Mullus surmuletus and M. barbatus) with different bottom habitats. Marine Ecology Progress Series, 150: 57-64.

LOMBARTE, A., L. RECASENS, M. GONZÁLEZ \& L.G. DE SOLA. 2000. Spatial segregation of two species of Mullidae (Mullus surmuletus and M. barbatus) in relation to habitat. Marine Ecology Progress Series, 206: 239-249.

LONGEPIERRE, S., A. ROBERT, F. LEVI \& P. FRANCOUR. 2005. How an invasive alga species (Caulerpa taxifolia) induces changes in foraging strategies of the benthivorous fish Mullus surmuletus in coastal Mediterranean ecosystems. Biodiversity and Conservation, 14: 365-376.

MACHIAS, A. \& M. LABROPOULOU. 2002. Intraspecific variation in resource use by red mullet, Mullus barbatus. Estuarine, Coastal and Shelf Science, 55: 565-578.

MATIĆ-SKOKO, S., N. STAGLIČIĆ, \& A. PALLAORO. 2010. State and perspective of Scorpaena scrofa and Mullus surmuletus - two highly valued species of eastern Adriatc artisanal fisheries. Rapp. Comm. int. Mer Médit. 39.

MATIĆ-SKOKO, S., N. STAGLIČIĆ, A. PALLAORO, M. KRALJEVIĆ, J. DULČIĆ, P. TUTMAN \& B. DRAGIČEVIĆ. 2011. Effectiveness of conventional management in Mediterranean type artisanal fisheries. Estuarine, Coastal and Shelf Science, 91: 314-324.

MAZZOLA, A., L. LOPIANO, T. LA ROSA \& G. SARA. 1999. Diel feeding habits of juveniles of Mullus surmuletus (Linneo, 1758) in the lagoon of the Stagnone di Marsala (western Sicily, Italy). Journal of Applied Ichthyology, 15: 143-148.

MAMURIS, Z., C. STAMATIS, K.A. MOUTOU, A.P. APOSTOLIDIS \& C. TRIANTAPHYLLIDIS. 2001. RFLP analysis of mitochondrial DNA to evaluate genetic variation in striped red mullet (Mullus surmuletus L.) and red mullet (Mullus barbatus L.) populations. Marine Biotechnology, 3: 264-274.

McCORMICK, M.I. 1995. Fish feeding on mobile benthic invertebrates: influence of spatial variability in habitat associations. Marine Biology, 121: 627-637.

MEHANNA, S. F. 2009. Growth, mortality and spawning stock biomass of the striped red mullet Mullus surmuletus, in the Egyptian Mediterranean waters. Mediterranean Marine Sciences, 10 (2): 5-17.

MEYER, C.G., K.N. HOLLAND, B.M. WETHERBEE \& C.G. LOWE. 2000. Movement patterns, habitat utilization, home range size and site fidelity of whitesaddle goatfish, Parupeneus porphyreus, in a marine reserve. Environmental Biology of Fishes, 59: 235-242.

MORALES-NIN, B. 1991. Parametros biologicos del salmonete de roca Mullus surmuletus (L. 1758), en Mallorca. Boletin del Instituto Espanol de Oceanografia, 7 (2): 139-147.

MOUTOPOULOS, D. \& K. I. STERGIOU. 2002. Length-weight and length-length relationships of fish species from the Aegean Sea, Greece. Journal of Applied Ichthyology, 18 (3): 200-203.

N'DA, K. \& C. DÉNIEL. 1993. Sexual cycle and seasonal changes in the ovary of the red mullet, Mullus surmuletus from the southern coast of Brittany. J. Fish Biol., 43: 229-244.

N'DA, K. 1992. Réegime alimentaire du rouget de roche Mullus surmuletus (Mullidae) dans le nord du Golfe de Gascogne. Cybium, 16: 159-167.

NIKOLSKY, G.V. 1976. The Ecology of Fish. 6th edition. New York: Academic Press, 352 p.

PAULY, D. 1984. Fish population dynamics in tropical waters: A manual for use with programmable calculators. International Center for Living Aquatic Resources Management (ICLARM Studies and Reviews 8), Manila, Philippines, 325 pp.

POLIS, G.A. \& K.O. WINEMILLER. 1995. Food Webs. Integration of Patterns and Dynamics. London: Chapman and Hall. 460 p.

RANDALL, J.E. 1967. Food habits of reef fishes of 
the West Indies. Studies in Tropical Oceanography, 5: 665-847.

REŇONES, O., E. MESSUTI \& B. MORALES-NIN. 1995. Life history of the red mullet Mullus surmuletus from the bottom-trawl fishery off the Island of Majorca (north-west Mediterranean). Marine Biology, 123 (3): 411-419.

ROSS, S. T. 1977. Patterns of resource partitioning in searobins (Pisces: Triglidae). Copeia, 561-571.

SHEPHERD, G. \& C. B. GRIMES. 1983. Geographic and historic variations in growth of weakfish, Cynoscion regalis, in the middle Atlantic Bight. Fishery Bulletin, 81: 803-813.

STAGLIČIĆ, N., S. MATIĆ-SKOKO, A. PALLAORO, R. GRGIČEVIĆ, M. KRALJEVIĆ, P. TUTMAN, B. DRAGIČEVIĆ \& J. DULČIĆ. 2011. Long term trends in the structure of eastern Adriatic littoral fish assemblages: Consequences for fisheries management. Estuarine, Coastal and Shelf Science, 94: 263-271.

STONER, A.W. \& R.J. LIVINGSTON. 1984. Ontogenetic patterns in diet and feeding morphology in sympatric sparid fishes from seagrass meadows. Copeia, 174-187.

TSERPES, G., F. FIORENTINO, D. LEVI, A. CAU, M. MURENU, A. ZAMBONI \& C. PAPACONSTANTINOU. 2002. Distribution of Mullus barbatus and M. surmuletus (Osteichthyes: Perciformes) in the Mediterranean continental shelf: implications for management. Scientia Marina, 66, 29-54.

TZANATOS, E., J. CASTRO, A. FORCADA, S. MATIĆSKOKO, M. GASPAR \& C. KOUTSIKOPOULOS. 2013. A Métier-Sustainability-Index (MSI25) to evaluate fisheries components: assessment of cases from data-poor fisheries from southern Europe. ICES Journal of Marine Science, 70 (1): 78-98.

UIBLEIN, F. 1991. Ontogenetic shifts in resource use and shoaling tendency related to body size in Red Sea goatfish (Parupeneus forsskali, Mullidae). Marine Ecology, 12: 153161.

UIBLEIN, F. 2007. Goatfishes (Mullidae) as indicators in tropical and temperate coastal habitat monitoring and management. Marine Biology Research, 3(5): 275-288.

VASSILOPULOU, V., C. PAPACONSTANTINOU \& G. CHRISTIDES. 2001. Food segregation of sympatric Mullus barbatus and Mullus surmuletus in the Aegean Sea. Israel Journal of Zoology, 47 (3): 201-211.

WARE, D. 1972. Predation by rainbow trout (Salmo gairdneri): the influence of hunger, prey density and prey size. Journal of the Fisheries Research Board of Canada, 29: 1193-1201.

WHITEHEAD, P.J.P., M.L. BAUCHOT, J.C. HUREAU, J. NIELSEN \& E. TORTONESE. 1986. Fishes of the North-eastern Atlantic and the Mediterranean. UNESCO, Paris, 2, 515-1007. 


\title{
Ishrana trlje kamenjarke, Mullus surmuletus u istočnom Jadranskom moru
}

\author{
Mišo PAVIČIĆ, Jasna ŠILJIĆ, Dajana BRAJČIĆ JURICA i Sanja MATIĆ-SKOKO* \\ *e-pošta: sanja@izor.hr
}

\begin{abstract}
SAŽETAK
Istraživana je ishrana trlje kamenjarke, Mullus surmuletus u istočnom dijelu Jadrankog mora. Analiziran je sadržaj želudca 203 jedinke $(11.5$ - $32.9 \mathrm{~cm}$ TL) prikupljenih pridnenom povlačnom mrežom koćom. Opće su prihvaćene metode i ključevi za determinaciju korišteni za određivanje sastava ishrane i determinaciju plijena. Istraživanjem je određeno 39 identificiranih vrsta plijena koji spadaju u 11 glavnih skupina: rakovi, puževi, školjkaši, ribe, žarnjaci, bodljikaši, mnogočetinaši, oblići, mahovnjaci, alge i krednjaci. Dominantna i poželjna kategorija plijena bili su dekapodni rakovi unutar svih veličinskih kategorija, dok je samo kod najvećih jedinki pronađena dominantnost školjkaša, a slijede ih mnogočetinaši i rakovi. Najveće jedinke također su pokazale veću raznolikost u konzumaciji različitih vrsta plijena i prosječno veći broj jedinki plijena u odnosu na manje ribe. Nije pronađena značajna razlika u ishrani između mužjaka i ženki $(p>0,05)$ i s obzirom na sezonu ( $p>0,05)$. Hranjenje širokim spektrom plijena bez značajnih varijacija u vezi sa spolom i sezonom sugerira da se trlja od kamena može prilagoditi pomacima u prostorno-vremenskim varijacijama obilja potencijalnog plijena. Prisutnost detritusa u probavnom traktu povezana je s načinom hranjenja istraživane vrste na muljevitim detritičnim dnima.
\end{abstract}

Ključne riječi: ishrana, Mullus surmuletus, Jadransko more 